Neddies"? The real trouble is, however, deeper and more serious. The public commissions seem to have become enticely persuaded of the Government's need of compromise. They are forever hiding behind their terms of reference. In their anxiety to produce recommendations that will be acceptable, they go to far too much trouble to avoid giving offence. The result is that their reports are vapid documents. This is not just a bad joke, but an enormous waste of busy people's time. There is an urgent need for a moratorium on the process, preferably without committee discussion in advance.

\section{Nuclear Compromise}

'THe long argument over what should happen to the British nuclear power industry now seems likely to be settled by a compromise. Rejecting the advice of those who favour a single design authority, Mr Anthony Wedgwood Benn told the House of Commons last week that he favours the formation of two "design and construction organizations", and that the Industrial Reorganization Corporation is to help in devising ways in which the two teams could be set up. The IRC has already had discussions with the industry, so it may be assumed that this pattern is one which the IRC thought feasible, but it will certainly not be easy to bring about.

The central part of the new structure, according to Mr Benn, will be the fuel company. This will be a public company, with its entire share capital owned initially by the Government. Later on, the fuel company will take up minority shareholdings in the two design and construction organizations-the rumour is that it will acquire 30 per cent of the shareholding. But it is not clear what exactly these organizations will be; Mr Benn's statement suggests that they will be "closely integrated" with the manufacturers of the main elements of nuclear boilers, which is generally taken to mean that they will be something like the existing consortia but incorporating elements of the Atomic Energy Authority.

If this interpretation is correct, the AEA will be losing its reactor group and its fuel business. Until legislation is introduced, the AEA will be responsible for looking after the fuel company for the Govcrnment, but this is only an interim measure. Ultimatelyperhaps in two years or so-the fuel company will pass entirely from the control of the AEA. These changes will mean that about 9,600 people at present employed by the AEA will have to shift to new organizations (or get out of the business altogether). About 9,000 of these will go to the public fuel company (it may be a few less, because some will stay to run Chapelcross and Calder Hall), where life is unlikely to be very different from life within the AEA. The other 600 are in the design team which will be split in some way between the two design and construction groups.

It is hard at the moment to see how the two groups can be put together. But at the end of last week, three of the companies which make boilers announced plans for a merger which will cross the boundaries of the existing consortia. The three companies, John Thompson Ltd, Clarke Chapman Ltd, and International Combustion Ltd, are to merge to form a company with a capital of $£ 32$ million. John Thompson and Clarke
Chapman are both members of the Nuclear Power Group, which has won the contracts for advanced gas cooled reactors at Hinkley Point B and Hunterston B. International Combustion, on the other hand, owns 50 per cent of Atomic Power Constructions, which is building the first AGR, Dungeness B. The other half of APC, Fairey Engineering, is thus left out in the cold for the time being, and may be tempted to link up with Nuclear Design and Construction, the third of the existing consortia. NDC is responsible for the last of the Magnox stations, Wylfa (which suffered a small fire this week) but has won no AGR contract yet, and is in a comparatively weak position.

While these elaborate musical chairs are in progress, existing contracts will have to be worked off. In addition, some of the companies have arrangements with European companies which they are anxious to preserve. This is going to make life very complicated for the next few years, until the new structure asserts itself. Meanwhile the AEA seems determined to maintain its grip on the Prototype Fast Reactor which is being developed at Dounreay and on the Steam Generating Heavy Water Reactor which has started operating at Winfrith. When the time comes, the AEA explains that both these designs can be offered on licence to the design and construction groups. The same will presumably be true of the high temperature reactor Dragon, which is being developed collaboratively by the European Nuclear Energy Agency at Winfrith. Mr Benn also visualizes the formation of an Atomic Energy Board on which the AEA, the design and construction organizations, the generating boards and the fuel company would be represented. The board, he said, would be concerned with research and development planning, export coordination and major policy matters.

Although, so far, these are only suggestions for discussion, they raise some interesting issues. The AEA, it is clear, will gradually work itself out of a job on the nuclear side if it is not allowed to initiate new designs. What will be left will be a rump AEA dedicated to diversification projects such as those which are in progress at Harwell, and to running the reactors at Chapelcross, Calder Hall, Winfrith and ultimately Dounreay. As for the design and construction organizations, it is hard to see that this is anything but another way of saying consortia. The fuel company will take a minority holding in the organizations, but who will take a majority holding ? One of the weaknesses of the existing consortia in international competition is that they have no capital to back them, because their constituent companies have been reluctant or unable to provide it. The proposals so far made will do nothing to correct this. In this sense, the proposals look like a complicated way of reducing the number of consortia to two. They may produce nothing but an unhappy compromise.

\section{BMA and Abortion Law}

The British Medical Association has adopted a curious attitude towards the new Abortion Act which came into operation on April 27 this year. At the annual conference held at Eastbourne last month, the association gave its assent to a view which in effect threatens doctors with expulsion if they carry out abortion on certain of the grounds permitted by the Act. 
This is tantamount to declaring that practices expressly permitted by Parliament are unethical.

The clause of the Act which has evoked this difference of opinion is the so-called social clause. This states that an abortion may be carried out when there is a risk to the physical or mental health of any of the existing children of the pregnant woman's family. As with the other clauses, two registered medical practitioners, acting in good faith, must decide that such a risk is greater than that involved in terminating the pregnancy.

The Council of the BMA regards this clause as unacceptable because it embodies the principle of acting on behalf of someone other than the patient herself. Presenting the council's views to the conference, Dr Gibson (see $B M J$, July 6, Supplement, p. 25) said that this principle was "completely at variance with medical tradition. Once that principle was abandoned, the way was opened to the legalization of practices which had been regarded elsewhere as com. pletely reprehensible."

The conference then debated the motion that the association should not oppose "that part of the Abortion Act referring to social grounds". The motion was lost, whereupon Dr G. R. Outwin proposed that "the ethical machinery of the association should not be invoked in respect of any member who may be properly associated with the termination of pregnancy within any of the provisions defined in the Abortion Act 1967". One speaker referred to the "Gilbertian" situation that could arise if doctors who had acted in accordance with the law were exposed to ethical proceedings to justify their behaviour. Another member said that doctors might, as individuals, disagree with the law, but he asked whether they had any inherent right to frustrate the intention of Parliament.

Dr Outwin's motion was also lost. This means that doctors who carry out abortions on the grounds permitted in the social clause are liable to be called before the Central Ethical Committee of the BMA. The committee has the power to recommend expulsion and its recommendations are in effect "rubber-stamped" by the council of the BMA. Dr J. Havard, the secretary of the Ethical Committee, asked to comment on the BMA's position towards the Act, said on the telephone this week that there are many practices which are not illegal, for example adultery, which are nevertheless unethical. In the opinion of his committee, there are practices permitted in the Abortion Act which are also unethical. He added that the logical extension of the principle embodied in the social clause, that the health of people other than the patient should be grounds for treatment, was that aggressive psychopaths should be castrated and euthanasia permitted.

Dr Havard agreed that the discretion given to doctors under the Act was likely to be restricted to some extent by their liability to appear before the Ethical Committee. He pointed out that the social clause had been inserted into the Act at a late stage of the debate in the House of Lords, on the motion of Baroness Summerskill, and that her amendment was not really necessary to deal with the kind of case she described. The House of Lords, Dr Havard said, is a predominantly nonmedical body and it is of course possible that a nonmedical body could be in error when legislating on medical matters. Dr Havard denied that the position adopted by the BMA is in any way contrary to the intentions of Parliament.
No doctor has yet appeared before the Ethical Committee for carrying out legal but unethical abor. tion, and because abortion cases, like other cases, are confidential, it is not clear on what evidence a doctor could be brought before the committee. The usual practice is for a member of the BMA to inform a doctor suspected of unethical practices that he proposes to bring the case to the attention of the Ethical Committee.

\section{Return of the Locusts}

Events have quickly justified the forebodings of the Anti-locust Research Centre, which was still hoping as recently as May this year that it would be possible to contain the swarms of desert locusts then being reported along the coasts of the Red Sea and Arabia by using conventional methods (see Nature, 218, 626; 1968). In the event, control has been inadequate and, according to reports reaching the centre from Saudi Arabia and Jordan, breeding in the Arabian peninsula has been unprecedentedly late and almost unbelievably successful. In Ethiopia and the Sudan, the situation is little better. Large numbers of swarms are breeding in the summer breeding areas.

The situation in the whole area has either become or is becoming out of control; if past experience is any guide, once swarm cycles of plague proportions have become established, they will persist for several years. Saudi Arabia has been facing a serious plague situation and the swarms, which have now begun to migrate into North Africa, will almost inevitably return later in the year, probably on an increased scale. On the other side of the Red Sea, swarms have already migrated from the Somali Republic into northern Ethiopia and it seems that by October and November they will migrate from there to Kenya. As things stand, any control measures other than extensive aerial spraying can be nothing more than local palliatives; even aerial spraying is unlikely to terminate the plague.

Since the end of the last major plague of desert locusts in 1963, the whole breeding area has been virtually free of locusts. Solitary locusts have been reported, but not large swarms. The primary cause of the resurgence, the first sign of which appeared late last year, seems to have been a series of heavy rains in several of the arid areas of Arabia and North Africa in the autumn of 1967 . The luxuriant vegetation provided the locusts with unusually favourable and prolonged breeding conditions. By February and March, when Mr J. Roffey of the Anti-locust Research Centre went to advise the Saudi Arabian Government's locust control officers, there were large bands of locust nymphs or hoppers on the coastal plains of Arabia. Attempts at control were only partially successful and large numbers of locusts escaped inland where they have since bred to plague proportions. In Ethiopia and the Somali Republic, the pattern has been similar although control in late 1967 and early this year was more successful.

The prolonged recession has also probably contributed to the resurgence by inducing a false sense of security and a relaxation of field surveys and control. Roffey's report from Saudi Arabia suggests that the control efforts there were too small and too late to be really effective. There has been no aerial spraying, 